\title{
ウイルス感染症流行制御のための下水疫学調査のエッセンス
}

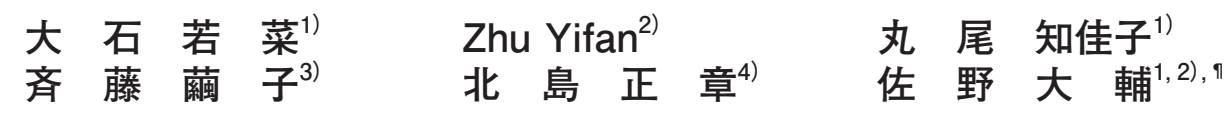

\section{Wastewater-based Epidemiology for Infectious Diseases: The Foundations and Future Perspectives}

\author{
Wakana OISHI ${ }^{1)}$, Yifan ZHU ${ }^{2)}$, Chikako MARUO' ${ }^{1)}$, \\ Mayuko SAITO $^{3)}$, Masaaki KITAJIMA ${ }^{4)}$ and Daisuke SANO ${ }^{1,2), ~}$
}

1) Department of Civil and Environmental Engineering, Graduate School of Engineering, Tohoku University, Aoba 6-6-06, Aramaki, Aoba-ku, Sendai, Miyagi 980-8579, Japan

2) Department of Frontier Sciences for Advanced Environment, Graduate School of Environmental Studies, Tohoku University, Aoba 6-6-06, Aramaki, Aoba-ku, Sendai, Miyagi 980-8579, Japan

3) Department of Virology, Graduate School of Medicine, Tohoku University, 2-1 Seiryo-machi, Aoba-ku, Sendai, Miyagi 980-8575, Japan

4) Division of Environmental Engineering, Faculty of Engineering, Hokkaido University, North 13 West 8, Kita-ku, Sapporo, Hokkaido 060-8628, Japan

\begin{abstract}
Wastewater-base epidemiology may be a promising approach to capturing the dynamics of the spread of diseases as well as emerging mutants in a catchment. Herein, we describe the key components of the wastewater-based epidemiology of viral infectious diseases, including the optimization of the methodology of the detection and quantification of viral genomes and the development of a back-calculation model to estimate the number of infected individuals. Early warning based on the influent viral concentration in a wastewater treatment plant may be feasible when it takes longer than one week to tally the number of patients of the target infectious disease by the currently used sentinel surveillance under the infectious diseases control law. The variables of a back-calculation model are categorized into two types: common variables irrespective of the type of infectious disease and variables specific to the infectious disease including shedding profiles of viruses. Greater effort is required to develop a robust back-calculation model against variability and uncertainty due to environmental, geological, and personal differences.
\end{abstract}

Keywords: COVID-19; Wastewater-based epidemiology; Early warning

\section{1. はじめに}

下水はヒトの代謝で排出された物質を運んでおり，食 品, 医薬品, 使用された違法薬物, 罹患している感染症 の情報などが豊富に含まれている。下水疫学調査は, 下 水中の化学物質や病原体を調査することで, 処理区域の 住民の健康に関する状況を把握するための方法である。 病原体が感染者の排泄物に排出される感染症の場合, 下 水を調べることで処理区域の流行状況を顕性・不顕性に かかわらず把握できるため, 臨床検査では得られない実 際の感染流行規模を推定することが可能であると考えら れている。最近, 新型コロナウイルス感染症 (COVID-19) をもたらす新型コロナウイルス（SARS-CoV-2）にも下 水疫学調査を適用できるかどうか国内外で検討が進めら れている。本稿では, SARS-CoV-2への応用を例として
取り上げながら, ウイルス感染症を対象とした下水疫学 調査の実装に必要な要素と課題を解説する。

\section{2. 下水疫学調査の実装事例}

水環境の污染を防止する目的で，下水中の有害物質の 監視や調査は長らく行われている。1990年代から, 農薬, 溶剂，重金属，医薬品やパーソナルケア製品に含まれる 有害物質が監視されている ${ }^{1)}$ 。2000 年代になると，合成 麻薬 MDMA やコカイン ・ヘロインの摂取状況の調査手 段として，下水の監視が注目されるようになった ${ }^{2{ }^{3}}$ 。下 水中に含まれる薬物やその代謝産物を測定し，使用頻度 や使用場所を推測することで，違法薬物対策を講じる上 で有益な情報や，犯罪捜査のための手掛かりを提供する ことが可能である。欧州諸国で結成された SCORE (Sewage Analysis CORe group Europe) は, 2011 年か

1 ) 東北大学大学院工学研究科 T980-8579 宮城県仙台市青葉区荒卷字青葉 6-6-06

2 ) 東北大学大学院環境科学研究科 $=980-8579$ 宮城県仙台市青葉区荒巻字青葉 6-6-06

3 ) 東北大学大学院医学系研究科 †980-8575 宮城県仙台市青葉区星陵町 2-1

4 ) 北海道大学大学院工学研究院環境工学部門 $\bar{\top} 060-0813$ 北海道札幌市北区北 13 条西 8 丁目

ๆ連絡先：daisuke.sano.e1@tohoku.ac.jp 
ら下水の監視による違法薬物使用状況調査を実施してお り, 現在ではオーストラリア, ニュージーランド, 中国で も導入が検討されている ${ }^{4 \sim 6)}$ 。特に, 国連条約で規制対象 に定められていない新精神作用物質 (New Psychoactive Substances : NPS）の早期検知が期待されている ${ }^{6)}$ 。下 水中の抗生物質の調査は, 処理区域における抗生物質の 使用状況調査に応用される ${ }^{7,8)}$ 。抗生物質の購入に処方箋 が要らず，ドラッグストアで購入できる地域における不 適切な服用状況の調査に有用である ${ }^{9)}$ 。

薬物や医薬品の使用状況の監視以外を目的とした試み もされている。大気中の PM2.5 およびPM10 と下水中の 気管支拡張薬濃度に有意な相関が見出されていることか $ら^{10)}$ ，季節性の大気污染による喘息やアレルギー症状へ の影響調査に下水疫学調査を適用できる可能性がある。

下水疫学調査は, 公衆衛生的介入のための科学的知見 としても利用された実績がある。WHO は, ポリオウイ ルス根絶計画の一環として，環境水や下水を調査するこ とで地域の感染者の存在を把握するポリオ環境水サーベ イランスを実施している ${ }^{11)}$ ○2013 年には, イスラエルに おける下水調査で野生株が検出され, 不活化ワクチンの 使用によるキャッチアップキャンペーンが実施された。 下水調査を強化した結果, 感染伝播が止まっていないこ とが判明したため, 生ワクチンの接種が行われた ${ }^{12)}$ 。

\section{3. 下水疫学調査で期待されていること}

\section{1 感染流行規模の把握}

下水中ウイルス濃度に基づき, 処理区域の感染流行状 況を把握する試みが行われてきた。下水中ウイルス核酸 濃度と患者数に相関があることがノロウイルス ${ }^{13,14)}$ ，お よび $\mathrm{A}$ 型肝炎ウイルスと $\mathrm{E}$ 型肝炎ウイルス ${ }^{15,16)}$ に関し 報告されている。 $\mathrm{A}$ 型肝炎ウイルスとノロウイルスにつ いては，下水中ウイルス核酸濃度に基づくアウトブレイ クの早期検知の可能性が示されている ${ }^{17)}$ 。仙台市では, ノロウイルス患者数の増加に先立ち, 下水処理区域での

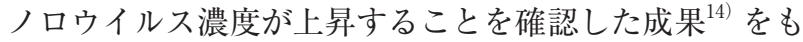
とに，下水調查を利用したノロウイルス早期検知システ ムが運用されている。流入下水中のノロウイルス GII ゲ ノム RNA 濃度を継続的に測定し, 増加が認められたら 警報を発信し, 衛生的な行動を呼びかけることで, 感染 性胃腸炎の流行を未然に防ぐ。情報発信については, 東 北大学が情報発信サイトをインターネット上 ${ }^{18)}$ に開設し て行っている。

SARS-CoV-2 は, 主に呼吸器系の細胞で増殖するが, ヒトの腸の細胞でも増殖しうることが示されている ${ }^{19)}$ 。 患者の糞便からの検出が確認されているほか, 下水試料 からのウイルス核酸の検出が相次いで報告されており, COVID-19 患者数と流入下水中 ${ }^{20,21)}$ と初沈污泥中 ${ }^{22)}$ のウ イルス核酸濃度に有意な相関が見出されている。さらに, 下水污泥中のウイルス核酸濃度は，検査サンプル採取日 でみた検査陽性の数より 0 ～ 2 日 $^{22)}$ ，入院患者数より 1 4 日 $^{22)}$ もしくは3〜 5 日 $^{23)}$, 感染者数公表より 6〜8 日 ${ }^{22)}$ 先行して増加すると推定された。世界的な流行初期には 検査・診断体制の不備に加え, 宿主側の不顕性感染の割 合, 粪便中へのウイルス排出時期, 病態のメカニズム（感 染後, 症状が悪化する日数等) について十分な知見が得 られなかったため, 感染者の把握が遅れ, 結果として下
水のおける検知が先んじているように観察された可能性 があるため, 下水中からの検出と発症の時間的関係性は 今後精査される必要があるが, 検査・診断体制の不備に より感染者の把握に遅れが生じている地域では, 下水疫 学調査が有用であることが示唆された ${ }^{22)}$ 。以上の報告か ら, 下水疫学調查による感染流行の早期検知への期待が 高まっている。

不顕性感染者や発症前の感染者は感染症の伝播に関与し うるが, 発症前に診断を受けることは稀である。COVID-19 については，健常者が旅行前あるいはイベント参加前に 自主的に検査を受ける動きがあるが，通常の感染症では 発症しなければ受診しないので, 感染から診断までに夕 イムラグがある。そのため, 病院での診断結果に基づき 感染症流行の予兆を捉え, 流行前に公衆衛生学的介入を 行うことは難しい。感染しているが発症していない状態 の感染者の排泄物からウイルスが排出され, 発症・診断 前に下水から検出できれば，下水中のウイルス濃度の増 加を検知することによってアウトブレイクを早期検知す ることが可能である。下水疫学調査に基づきアウトブレ イクを早期検知できれば，都市のロックダウンや外出自 肃要請を発令する際の科学的根拠として下水中ウイルス 濃度デー夕を活用できるだろう。すでに感染が流行して いる地域においては, 下水中ウイルス濃度から感染者数 の増減を診断に先立って推定できれば，医療機関への負 荷を予測し，必要物資や人的資源を効率的に分配するこ とも可能になるかもしれない。また，定期的な調査によ って下水中ウイルス濃度の減少傾向を監視し, 検出限界 值以下になる状況を確認することは感染者数の減少を表 し, 必ずしも集団免疫の獲得を意味しないが, 収束判断 のひとつの指標となりうる。

\section{2 変異解析による地域間流行株の比較}

ウイルスを対象としたメタゲノム解析手法を下水試料 に適用することで，下水中ウイルスを網羅的に検出でき る可能性がある。全国に散在する下水処理場から下水試 料を採取し，下水中ウイルスゲノムを定期的に解析する ことで, 空間的・時系列的なウイルスゲノム解析が可能 になり，地域間の流行株の比較やウイルス集団の進化の 様相を明らかにするための手掛かりとなる。大村 (2020) は，全国の下水処理場におけるゲノム配列レベルの早期 検知によるウイルス感染症流行防止策を提言している ${ }^{24)}$ 。 全国の下水処理場で流入下水を採取し, 次世代シーケン サーで下水中に存在する病原ウイルスのゲノムの塩基配 列を解読し, ウイルスの種類に加えて感染性・病原性に 関わる遺伝子配列に基づき，ウイルスゲノム配列がクラ スター分類されたデータベースを作成する。 SARS-CoV-2 に関しては, 変異株のまん延が懸念されている, レセプ ター結合に係る N501Y 遺伝子が挙げられる ${ }^{25)}$ 。定期的な 下水分析において, 以前に検出されていないゲノムをも つ変異株が検出された場合, 同じクラスターに属する株 の感染性・病原性の特徵に基づき, 未知の変異株の特徴 を推定することで, ワクチンや治療薬の効果への影響を 予め評価する等, 感染症流行を未然に防ぐための対応に 貢献できる可能性がある ${ }^{20)}$ 。

\section{4. 下水疫学調査実装のための要素}

本章では, ウイルス全般を対象とし, 下水疫学調査を 
実装するための要素として, 下水からウイルスを検出す る手法の最適化および検出結果から感染流行状況（感染 者数の増減）を推定するためのモデルの構築について解 説する。

4.1 安定, 迅速かつ簡便な下水試料からのウイルス検出 下水疫学調査の実現のための第一の要素は, 下水中ウ イルスの検出および定量である。下水中ウイルス濃度の 定量は, 試料採取, 下水試料濃縮, ウイルス核酸抽出, 逆転写（RNA ウイルスの場合のみ）およびリアルタイム PCR による定量の順に行われる（図 1)。下水中ウイルス 濃度は極めて低い。正確な下水中ウイルス濃度デー夕を 得るためには, 下水試料の採取方法と濃縮方法の最適化 が必須である。

\section{1.1 採取法の最適化}

下水の採取法には, 連続的に採取する方法 (Composite サンプリング）と単発的に採取する方法（Grab サンプリ ング）がある。Composite サンプリングで採取された試 料はすべて混合してから分析されるのに対し, Grabサン プリングで採取された試料は 1 つ 1 つ別々に分析される。 一般的に, 下水中ウイルス濃度は対数的に変動する。 Composite サンプリングでは, 調査時間内の下水中ウイ ルス濃度の算術平均をとるため, 下水中ウイルス濃度が 低く, かつ時間的な変動が大きい場合にも高い濃度でウ イルスを検出しやすい ${ }^{26)}$ 。Grab サンプリングではウイル ス濃度が検出可能なレベルにまで上昇する瞬間を逃す可 能性があるため, 事前に日内変動を調査することが望ま しい。感染者数が少なく, 下水中ウイルス濃度が低いこ とが予想される場合に，まず Composite サンプリングを 行うことが選択されうる。一方で, Composite サンプリ ングでは調查時間内に採取した下水をすべて混合するた め, 下水中ウイルス濃度の日内変動に関する情報が得ら れない。Grabサンプリングでは, サンプリング時刻にお けるウイルス濃度が得られるので, サンプリングと分析 の回数を増やすことができれば, ウイルス濃度の日内変 動に関する情報を得ることも可能である。サンプリング

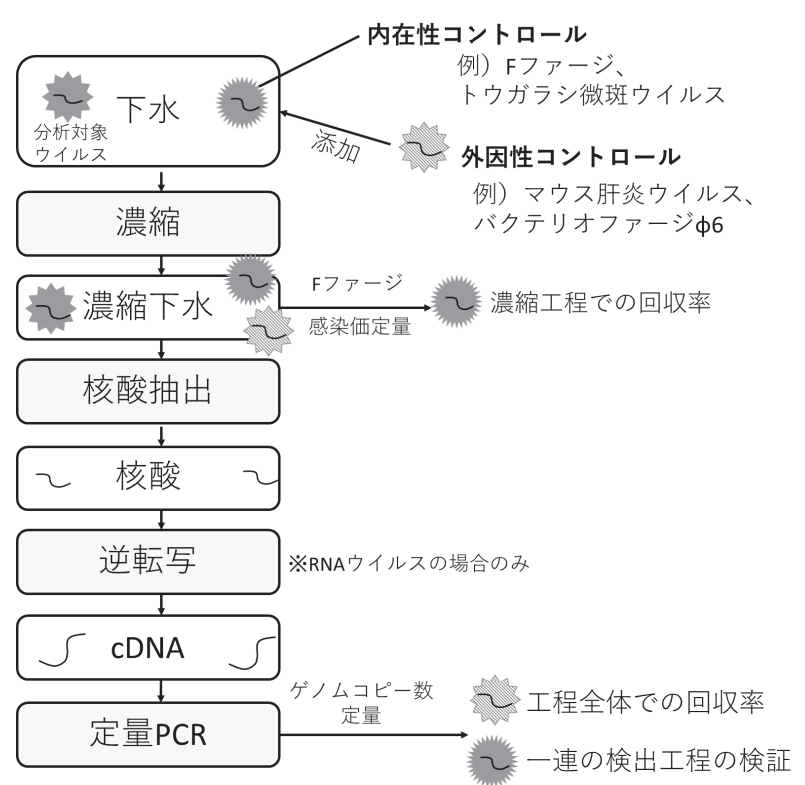

図 1 下水分析工程
と下水分析にかかるコストや労力を考慮し, 目的に応じ て最適な採取方法を検討する必要がある。

サンプリング地点は下水疫学調査の目的に応じて決定 される。下水処理場の処理区域全体の感染流行状況を調 査する場合, 下水処理場の流入水を採取する。処理区域 をさらに地域ごとに区分けして感染流行状況を調査する 場合，マンホールやポンプ場から採取することになる。 下水処理場の最初沈殿池の污泥中ウイルス濃度を測定し, 結果を感染流行の時系列的な解析に適用する場合には, 沈殿池内での污泥の滞留時間を考慮する必要がある。

固形分への吸着割合の多いウイルスの場合，下水の液 相からの検出に加え, 浮遊物質からの検出も検討すべき である。Kitamuraら（2020）は，下水試料を遠心分離 し, 得られた沈殿物および上清中のウイルス核酸濃度を 調査している。トウガラシ微斑ウイルスは, 沈殿物より も上清から継続的に高濃度で検出された一方で, SARS-CoV-2 は，上清から検出されない場合でも，同一 試料の沈殿物からは検出されている ${ }^{27)}$ 。SARS-CoV-2 と 同じくエンベロープウイルスであるマウス肝炎ウイルス (MHV) とバクテリオファージ $\phi 6$ が非エンベロープウ イルスと比較して, 液相内よりも浮遊物質内に分配され やすいことが報告されていること年) からも，エンベロー プウイルスの下水からの検出では浮遊物質も調べるべき である。

\subsection{2 濃縮方法の最適化}

下水中のウイルス濃度は低いため, 下水試料からのウ イルス核酸の検出やウイルスゲノム解析を実施するため には，まず下水を濃縮する必要がある。下水の濃縮方法 については様々な方法が考案されており, 先行研究 ${ }^{29)} に$ 詳しい。SARS-CoV-2 の検出では, 陰電荷膜吸着 - 直接 RNA 抽出法 ${ }^{30 \sim 32)}$, 陰電荷膜破砕型濃縮法 ${ }^{31)}$, 限外万 過 $^{20,30,32,33)}$, PEG 沈殿法 ${ }^{32,34)}$ ，アルミニウム凝集 ${ }^{21,35)}$ な どが報告されている。污泥試料から検出する場合, 濃縮 操作は行われず, 固形分から直接核酸を抽出するキット を使用する ${ }^{22)}$ 。日本下水道新技術機構は, 日本水環境学 会 COVID-19 タスクフォースと共同で, 2020 年 12 月に 下水中の新型コロナウイルス遺伝子検出マニュアル（暫 定版）を公表した。

下水の濃縮で注意すべき点は, ウイルス粒子の構造の 違いによって最適な濃縮方法が異なることである。ノロ ウイルスや A 型肝炎ウイルスなどの多くの腸管系ウイル スは，核酸がタンパク質の殼で覆われた構造をしている。 一方で, SARS-CoV-2 の最外款構造は脂質二重膜と糖夕 ンパクから成る被膜（エンベロープ）である。濃縮には, ウイルス表面の性状（疎水性の度合いや電荷など）や $\mathrm{pH}$ 安定性などが影響する。そのため, 検出の対象ウイルス の最外殼構造を考慮し, 最適な濃縮方法を検討する必要 がある。

\subsection{3 逆転写と定量}

濃縮試料から抽出されたウイルス核酸は, リアルタイ ム PCR で定量される。RNA ウイルスの場合, 逆転写反 応により合成した cDNA をリアルタイム PCR で定量す る。逆転写と定量の工程では, 下水に含まれるフミン酸 によって逆転写およびポリメラーゼ反応が阻害され, 最 終的な定量值が過小評価されることがある ${ }^{29)}$ 。RNA 抽出 液を希釈してから逆転写することで, RNA 抽出液中の阻 
害物質の影響を低減できる ${ }^{29)}$ が, 下水試料中の検出対象 ウイルス濃度が非常に低い場合には, ウイルス核酸を検 出限界末満まで希釈してしまい検出できない恐れがある。 逆転写酵素とポリメラーゼへの阻害の影響を予め評価し ておき，阻害の影響を受けづらい試薬を選択することが 望ましい。

リアルタイム PCR では, ウイルス核酸の全領域のう ち，一部の限定的なゲノム領域を標的として検出を行う。 検出に用いるプライマー・プローブセットには様々な配 列が用意される。使用するプライマー・プローブセット によって検出感度が異なることがあるため, 複数のプラ イマー・プローブセットを事前に評価するべきである。 例えば, SARS-CoV-2についてはヌクレオタンパク領域 を対象とした検出用プライマー・プローブセット 3 種類 (CDC N1, N2, およびN3）を下水からの検出に適用した 場合, これらの間で検出感度が異なることが報告されて いる ${ }^{20)}$ 。ノウイルス GI および GI 下水中濃度の定量に おいても, US.EPA, ISO および厚生労働省で標準化され た検出プロトコール間で検出感度に有意な差があること が報告されている ${ }^{36)}$ 。

\subsection{4 プロセスコントロール}

濃縮, ウイルス核酸抽出, 逆転写および定量の過程で は, 何らかの原因で検出対象ウイルス核酸の物理的損失 または検出阻害が生じるため, 下水中に存在するウイル スを $100 \%$ 回収して定量することは困難である。まず，下 水試料の濃縮時およびウイルス核酸抽出時の損失がある。 逆転写反応における cDNA 合成効率の低下, および PCR における遺伝子増幅効率の低下も生じうる。濃縮・検出 過程で著しい阻害が生じた場合には, 正確なウイルス核 酸の定量を行うことができないため, 濃縮操作からのや り直しやデータの不採用 (破裹) 等が行われる。

下水中ウイルス核酸濃度を正確に評価するために，プ ロセスコントロールを使用し，各過程で生じた損失およ び阻害を検出する。濃縮, ウイルス核酸抽出, 逆転写・ リアルタイム PCR それぞれの過程であらかじめ試料に プロセスコントロールを既知量添加し, 最終的に何\%回 収されたか（回収率）を計算することで検出プロセスの 有効性を評価する。一般に, 全体の回収率が $10 \%$ 以上で あれば，大きな損失や阻害は生じていなかったと判断す るが，1\%以上の回収率が得られていれば問題ないと判断 する場合もある ${ }^{29)}$ 。

濃縮から定量までのプロセスコントロール（Whole process controls：WPCs）は, 最外殼構造や粒子の大き さ, 疎水性 / 親水性, $\mathrm{pH}$ 安定性等の性質が目的ウイル スと類似のウイルスが使用される。また，プロセスコン トロールの回収率は試料の種類によっても異なる ${ }^{37)}$ 。検 出対象ウイルスごと, 試料ごとに最適なプロセスコント ロールの検討が必要である。

外因性コントロールは, 下水濃縮前に下水試料中に既 知量を添加し, 添加量に対する回収量を計算することで 回収率を評価するために使用される。ノロウイルスと $\mathrm{E}$ 型肝炎ウイルスの下水試料からの検出には, それぞれ, 非エンベロープウイルスであるマウスノロウイルスとメ ンゴウイルスが使用されている ${ }^{14,15)}$ 。SARS-CoV-2につ いては，エンベロープウイルスである MHVやバクテリ オファージ $\phi 6$ が使用されている ${ }^{32,38)}$ 。
下水試料に添加した外因性コントロールの回収率は, 下水の液相からの検出対象ウイルスの回収率を代表しう るが, 浮遊物質からの抽出効率を表さないため, 浮遊物 質に吸着して存在している検出対象ウイルスの回収率を 必ずしも表さない。下水の浮遊物質中ウイルス濃度を測 定する場合には，浮遊物質中に元々存在するウイルスを 内在性コントロールとして測定し, 抽出効率を評価する ことが推奨される。内在性コントロールとしては, F フ アージやトウガラシ微斑ウイルスが用いられる。F ファ ージについては感染価を測定することで, 濃縮工程のみ の回収率を算出できる。濃縮工程においてウイルスと共 に濃縮される有機物等による感染価測定阻害が懸念され る場合は，Fファージ培養液を濃縮下水および緩衝液や 滅菌水に既知量添加し, 感染価を比較評価することが望 ましい。下水中でのトウガラシ微斑ウイルスの存在濃度 は明確な季節変動を示さず，比較的一定であること ${ }^{39)}$ か ら, 下水試料中に元々存在するトウガラシ微斑ウイルス を測定することで, 一連の検出工程に大きな問題が生じ ていないかどうかを確認することができる。Fファージ やトウガラシ微斑ウイルスを内在性コントロールとして 用いることのデメリットは，エンベロープをもたないた め, その濃縮回収率は SARS-CoV-2 の濃縮回収率を十分 に反映していないと考えられることが挙げられる。それ ぞれのプロセスコントロールの特徴を理解した上で, 複 数のプロセスコントロールを併用することも推奨される。

\section{2 下水中ウイルス濃度を用いた感染症流行の早期検知}

4. 2.1 ウイルス検出情報の公表と感染者把握に関する 制度

下水疫学調査により自治体による感染者数公表に先立 つ早期検知を試みる場合, 感染症の診断から自治体が警 報を発令するまでに下水分析結果を得られるかどうかが 第一の論点となる（図 2)。国内における感染症発生事例 の報告システムは, COVID-19 を含む新型インフルエン ザ等感染症と感染性胃腸炎を含む 5 類定点把握疾患では 対応が異なることを考慮しなければならない。現行の感 染症法において，インフルエンザやノロウイルス感染症 を含む感染性胃腸炎は, 患者数が多数で全数を把握する 必要のない疾患（定点把握疾患）に分類されており, 指 定医療機関は患者数を週単位で保健所に届け出ることが 規定されている ${ }^{40)}$ 。自治体は, 患者数を集計し, 指定医 療機関からの患者報告数が一定レベルを超えた場合に注 意喚起を促すために警報を発信する。つまり，患者が発 生して医療機関を受診してから自治体が警報を発信する までにおよそ 1 週間を要する（図 2)。ノロウイルスに関 しては, 下水処理場の流入下水中ウイルス濃度が感染性 胃腸炎患者報告数と遅れが \pm 0 週未満で相関し, 下水処 理場への流入下水の分析によって医療機関の報告よりも 早期に感染の流行を検知可能であることが確認されてい

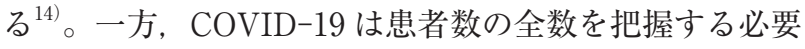
があり，現状では患者数を毎日集計し，報告することが 規定されている ${ }^{14)}$ 。したがって，24 時間以内に下水のサ ンプリングから分析が完遂して警報発令に関する意思決 定が行われない限り, 下水処理場の流入下水中ウイルス 濃度に基づく早期の警報発令は難しいと考えられる。今 後, COVID-19 が仮に定点把握疾患になり，自治体によ る患者数の把握から警報発令がインフルエンザや感染性 


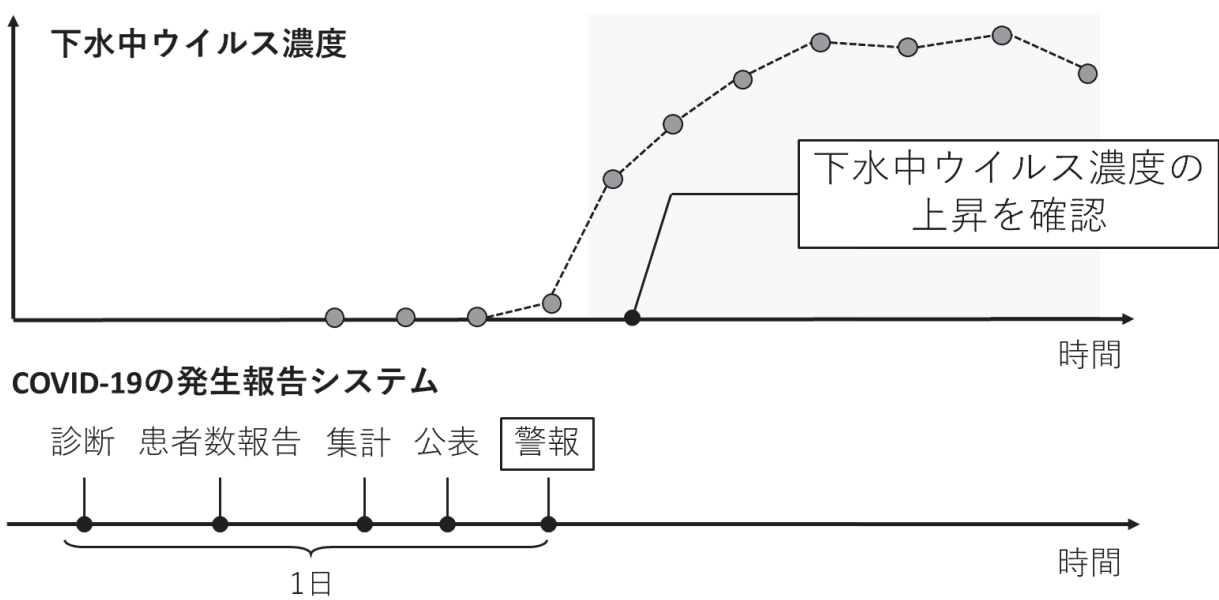

感染性胃腸炎の発生報告システム

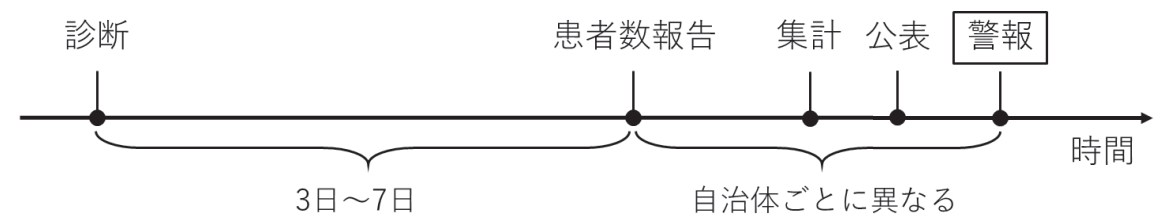

図 2 診断に基づく感染症流行警報システムと下水中ウイルス濃度の時系列的な比較。図に示 したデータは実際の值ではない。

(1)ウイルス排出プロファイル

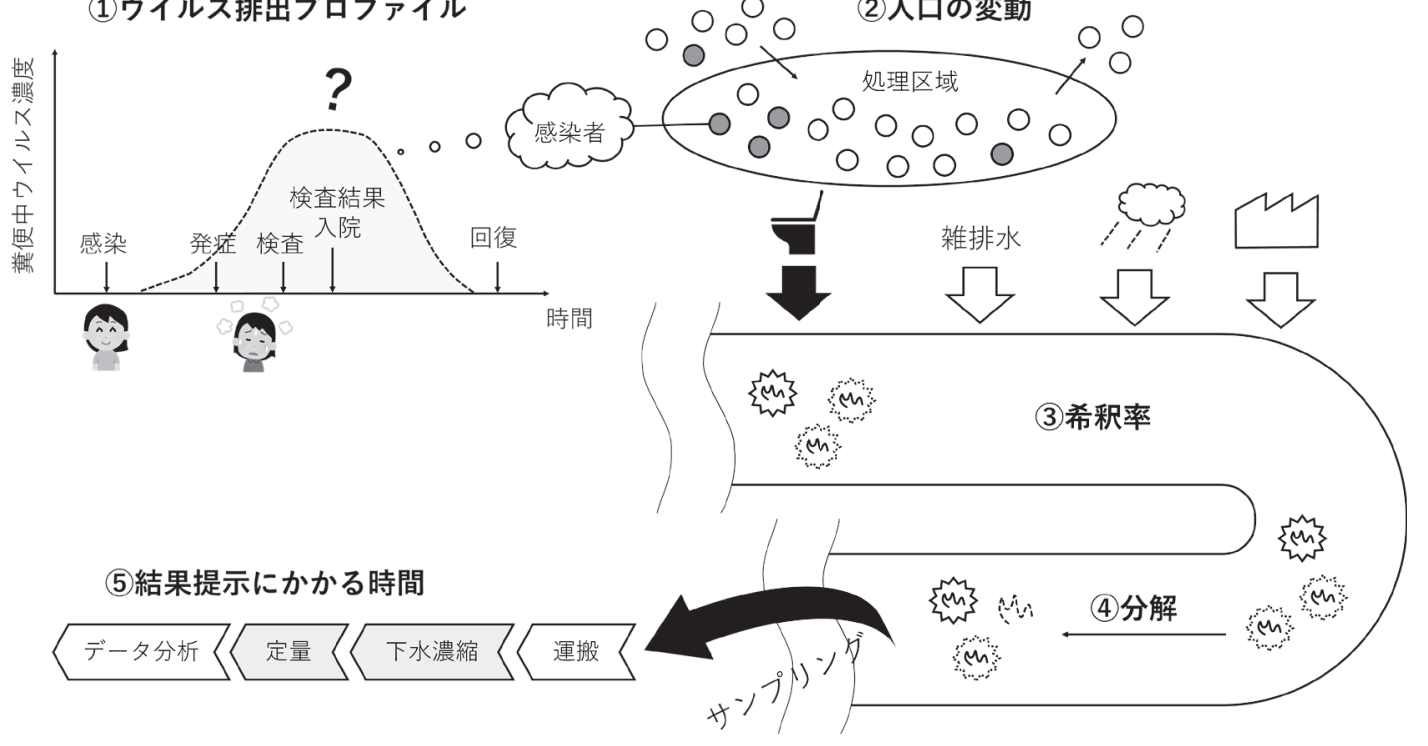

図 3 感染者数推定モデルで考慮すべき事項

胃腸炎と同じ体制で実施されるようになった際には，集 計および報告の頻度が週単位となるため, 警報発令のた めの根拠として下水処理場の流入下水中ウイルス濃度を 利用する優位性は高まると考えられる。

したがって, 特に新型インフルエンザ等感染症を対象 とする場合, 感染症がまだ流行していない地域で感染症 の流行を早期に検知するためには, 少数の感染者 (発症 者）に由来する粪便を含む下水を確実に捕らえるために， なるべく排出源に近いところでサンプリングすることが 望ましいだろう。例えば，処理区域が広い下水処理場ほ どウイルスを含む下水が居住地域から下水処理場に到達
するまでに希釈されるため, 下水処理場への流入水より も，居住地域付近のマンホールや建物敷地内に設置され た浄化槽からのサンプリングの方がウイルスを捕らえる には望ましい可能性がある。サンプリング位置をよく検 討した上でのマンホールや浄化槽からのサンプリングに よる感染症流行地域の早期特定が期待される。また, ウ イルスを糞便中に排出し始めるのが, 感染, 発症, 検査, および検査結果の公表のどの夕イミングにあたるのかを 把握する必要がある（図 3 (1)）。発症するより前にウイル スが粪便中（下水中）に排出されない場合, 臨床検査の 結果に先立って感染流行を捉え, 早期に対策を講じる, 
という下水疫学調査に「早さ」のアドバンテージを求め ることは難しくなるであろう。

\subsection{2 下水中ウイルス濃度を用いた感染者数推定モデル}

アウトブレイクの早期検知において検出可能な最少感 染者数は, 下水試料中のウイルス濃度が検出限界值を超 えるときの感染者数である。アウトブレイクの早期検知 を実用化するためには, 下水試料中のウイルス濃度で検 出可能な最少感染者数を調査対象地域ごと事前に把握す る必要がある。最少感染者数をなるべく少なく設定する ために，下水中ウイルス濃度が低濃度でも高感度に検出 可能な検出手法を確立することが望ましい。

感染者数の増減を推定するためには, 下水中ウイルス 濃度と感染者数の関係を表すモデルが必要になる。感染 者数推定モデルは, 基本的には, 下水中ウイルス濃度か ら逆算して処理区域の感染者数を割り出す数式になる。 簡単に記述すると, 下水中ウイルス粒子数を感染者 1 人 が糞便中に排出するウイルス粒子数で除算することで感 染者数を推定することになる ${ }^{17)}$ 。このとき, 感染者が糞 便に排出するウイルス粒子数が希釈されることを考慮す るために下水流量で補正を行う必要がある。実際には, 上記の逆算過程に下水道やサンプリングと分析に起因す る感染症に共通の変数と感染症ごとに異なる変数が存在 し, 複数の変数に対して仮定を置く必要があり, それら 変数の時間的・空間的変動性と不確実性をどう扱うかが 課題となる（表 1$) 。$

\section{（1）感染者に起因する要素}

まず，臨床検査によって得られるデー夕に基づき，ウ イルスを糞便中に排出する感染者の割合を設定する必要 がある。さらに, 感染してから粪便中にウイルスが排出 されるまでにかかる時間や, 糞便中ウイルス濃度の時間 的推移といった粪便中ウイルス排出プロファイルが必要 である（図 3 (1)）。ノロウイルスに関しては, 感染者から の糞便中ウイルス排出期間は平均 6.9 日であり, 不顕性

表 1 感染者推定モデルで考慮すべき変数またはパラメー夕

\begin{tabular}{l}
\hline 感染症ごとに異なる項目 \\
\hline 感染者に起因する項目 \\
糞便中にウイルスを排出する感染者の割合 \\
感染してから糞便中にウイルスを排出するまでの時間 \\
糞便中ウイルス濃度の時間的推移 \\
糞便中にウイルスを排出する期間 \\
ウイルスの下水中での挙動に起因する項目 \\
ウイルス核酸の下水中分解速度 \\
分析対象（例 : 污泥, 流入下水) \\
下水試料濃縮後の分析対象 (例 : 液相のみか固形分を含めるか) \\
\hline 感染症ごとに共通の項目 \\
\hline 下水・下水道に起因する項目 \\
処理区域人口の日内変動 \\
家庭䧱排水, 工場排水, 雨水による希釈率 \\
管路の継ぎ目などからの地下水の流入量 \\
下水流量 \\
サンプリングと分析に起因する項目 \\
下水中ウイルス濃度の日内変動と試料中ウイルス濃度の関係 \\
サンプリングから分析までにかかる時間
\end{tabular}

感染者の排出期間が 5.8 日間であったのに対し，顕性感 染者では 9.8 日間であったことが報告された ${ }^{41)}$ 。ウイル ス排出濃度の個人差も重要である。感染者の糞便中の核 酸濃度は, SARS-CoV-2 の場合, 糞便 $1 \mathrm{~g}$ あたり $10^{4}$ $10^{8}$ コピー ${ }^{42)}$ であり, 個人差が大きいことが報告されて いる。ノロウイルスの場合, $10^{5} \sim 10^{9}$ コピーと報告され ており ${ }^{43)}$, SARS-CoV-2 よりおよそ $1 \mathrm{Log}$ 高濃度で排出 される。問題は, このような感染者の糞便中ウイルス濃 度デー夕は, 通常, 病院での臨床検査で得られるもので あり, 受診しない感染者や不顕性感染者については得ら れないことである。モデル上は仮定を置くことになるが, 感染者の個人差に起因する不確実性は大きいことが予想 される。

\section{（2）下水および下水道に起因する要素}

処理区域の人口をモデルの変数とする場合, 特に都市 部においては通勤者や旅行者が含まれるので, 日内の人 口変動を無視できない（図 3 (2)）。また, 下水道は家庭雑 排水, 雨水, 工場排水も受け入れることから, トイレ排 水は下水処理場に流入する時点で希䣋されている（図 3 (3)）。人口の変動と希釈の影響は, ヒトの排泄物の負荷を 反映する指標を測定することで推定できると考えられる。 指標として満たすべき条件は，定量が容易であること， 下水中濃度と人口に相関があること, 安定であること $(24$ 時間で分解率 $10 \%$ 未満), 下水道中における平均滞留時 間内の分解が $10 \%$ 未満であることとされている ${ }^{44)}$ 。ヒト が摂取する特定の食品・医薬品の代謝産物 (Exogeneous marker) では, アルコールやイブプロフェンが適当であ るが, 地域ごとの消費習慣に影響を受けることから，有 用なデータが得られないことや地域ごとに偏ったデータ になってしまう懸念がある ${ }^{6)}$ 。一方で, アンモニアと 5-hydroxyindoleacetic acid（5-HIAA）は，安定して排 出される代謝産物 (Endogenous marker) である ${ }^{6)} 。 ア$ ンモニアは測定も容易で, リアルタイムに測定可能であ る $^{45)}$ 。5-HIAA は, 1 人 1 日当たり尿中に $3.44 \mathrm{mg}$ 排出 されることがわかっている ${ }^{46)}$ 。トウガラシ微斑ウイルス は多くの地域・試料から高い濃度で検出されていること から, 環境水の糞便污染の指標として提案されている ${ }^{47)}$ 。 トイレ排水の希釈率を推定するための標準化マーカーと しても有用かもしれないが, まだ実用化には至っていな い。人口の変動については, スマートフォンから得られ る位置情報デー夕を利用することで, 処理区域における 人口の流出入を把握できるが, 取得可能なデータの量は, デバイスの保有状況やプライバシー設定に制限される点 に注意すべきである。

\section{（3）ウイルスの下水中での挙動に起因する要素}

ウイルス核酸が下水中で分解されることも考慮するべ きである（図 3 (4)）。SARS-CoV-2 の場合, ウイルス核 酸が未処理下水中で $1 \log$ 減少するのにかかる日数は,

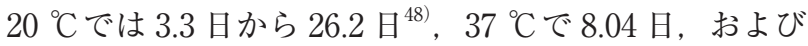
$4{ }^{\circ} \mathrm{C}$ で 27.8 日であり ${ }^{49)}$, 水温の上昇に伴い減少速度は増 大することが報告されている。内在性コントロールとし て使用される F ファージの場合, $20{ }^{\circ} \mathrm{C}$ では 7.2 日であり, $4{ }^{\circ} \mathrm{C}$ では 21.2 日と報告されている（ただし, 初沈越流水 中, 暗条件 ${ }^{50)}$ 。ノロウイルス GII の場合, $36{ }^{\circ} \mathrm{C} て ゙ 46$ 日 間, $21{ }^{\circ} \mathrm{C}$ と $3{ }^{\circ} \mathrm{C}$ で 115 日間であり ${ }^{51)}$, SARS-CoV-2 よ りも長期間残存する。ウイルス核酸の分解速度は, 下水 
の性状に影響を受けるので，地域ごとの下水試料中にお けるウイルス核酸の分解速度を調査すべきである。

\section{（4）サンプリングと分析に起因する要素}

ウイルスが下水中に排出されてからサンプリング地点 まで到達するまでにかかる時間は, 居住地域とサンプリ ング地点間の下水管路の距離や下水流量で決まるので, 地域ごとに異なるが, 流量の測定によって推定可能と考 えられる。Grabサンプリングではサンプリングした試料 を1つ1つ別々に分析するため, 1 日のある時点におけ るデー夕が得られる。1 日の下水中ウイルス総量を求め る場合には, 下水中ウイルス濃度の日内変動を事前に調 查しておき, 不連続的な下水試料中ウイルス濃度から下 水中ウイルス総量を推定するための換算式が必要である。 サンプリングから定量結果を得るまでに要する時間は, サンプル輸送手段や試料調整の方法によって異なる。

先行研究では, すべての感染者がウイルスを糞便中に 排出するという仮定のもとに, 下水中ウイルス核酸量か ら感染者数が推定されている ${ }^{30)}$ 。筆者らの最新の研究で は, 糞便中にウイルス核酸を排出する感染者の割合, 感 染期間における粪便中ウイルス排出濃度推移および下水 流量に正規分布を仮定し, 公表された感染者数から下水 中ウイルス核酸濃度が推定されている ${ }^{52)}$ 。感染者推定モ デルには多数の変数が存在する（表 1)。さらに, 処理区 域内の人口推移, 感染者数の推移, 感染者の糞便中ウイ ルス排出プロファイル，降雨や家庭雑排水および工場排 水の流入量はすべて短期的に変動する。加えて, 個々の 感染者の免疫など感染の特徵の違いに起因する不確実性 を含む。つまり, それらの関数である感染者推定モデル は時間的変動とパラメータの不確実性を含んだ動的なモ デルとなる。

\section{5. おわりに}

本稿では, ウイルス感染症流行制御に下水疫学調査を 活用する上で必要な検討事項を解説した。まず, 対象と するウイルス感染症の感染症法上の分類（新型インフル エンザ等感染症と 5 類定点把握疾患）および報告制度に 留意すべきである。新型インフルエンザ等感染症を対象 とする場合, 下水処理場の流入下水の分析によって, 現 行の警報発信システムに先立つ流域レベルの早期検知は 難しいため, 下水処理場よりも感染者の発生場所付近で のサンプリングが望ましい。感染者数推定モデルは, 感 染症に共通の変数と感染症ごとに特有の変数を用いて構 築される。COVID-19 に関しては, 感染者数推定モデル の構築に必要な知見の蓄積が十分でない。特に, 感染者 のウイルス排出プロファイルは，モデルに重要なパラメ ータであるため, 臨床現場での生体試料の収集・分析に 併せて, 個人差に起因する変動を表現可能なモデルの開 発が要になる。下水試料からのウイルス検出手法につい ても検討を継続し, 最適な方法を確立すべきである。特 に, 我が国のように感染者数が少ない地域への適用のた めには, 検出の感度向上と下水処理場よりも発生源付近 を対象とするサンプリング計画が重要であり, COVID-19 への下水疫学調査適用可能性は, 引き続き慎重に検討さ れるべきである。

下水疫学調査の社会実装に向けて, 他にも議論すべき ことがある。例えば，日常的な下水分析の実施体制があ
る。未処理の下水試料を採取・分析する際には，試料取 扱者や近隣の安全に配慮し, 保護具の着用等の適切な対 策を行うことが望ましい。試料の輸送に関しては，感染 性物質の輸送規則 ${ }^{53)}$ に規定される病原体の種類に応じた 適切な相包・発送方法に従うことが推奨される。試料数 にも依るが, 下水の採取から試料の前処理, 定量, デー 夕処理に必要な人的資源と予算の用意を要する。筆者ら は, 分析にかかるコストを試薬代のみで 1 試料あたり約 5,000 円（核酸抽出，逆転写，定量 PCR）と概算してお り, 人件費や機器費用等も併せると日常的な下水分析は 決して安くない。下水疫学調査を行う機関に対して, 予 算状況に見合う最適な方法を提供できるように，複数の 下水中ウイルス核酸検出プロトコールを開発することは, 下水疫学調査の実装のための一つの手段である。また, 下水疫学調査で得られた結果を効果的に活用するための 仕組みも重要である。公衆衛生部門との連携のもと, 意 思決定部門や住民への有効な発信方法の開発や効果的な 介入策を講じる必要がある。

\section{謝 辞}

本研究は, 国立研究開発法人日本医療研究開発機構 (AMED) の令和 2 年度新興 - 再興感染症研究基盤創生 事業（海外拠点研究領域）「フィリピン研究拠点における 感染症国際共同研究」（課題番号：JP20wm0125001）の 一環として行われました。

（原稿受付 2021 年 1 月 20 日） (原稿受理 2021 年 5 月 7 日)

\section{参 考 文 献}

$1)$ Daughton, C.G., Ternes, T.A., 1999. Pharmaceuticals and personal care products in the environment: agents of subtle change? Environmental Health Perspectives 107(SUPPL. 6), 907-938.

2 ) Zuccato, E., Chiabrando, C., Castiglioni, S., Calamari, D., Bagnati, R., Schiarea, S., Fanelli, R., 2005. Cocaine in surface waters: a new evidence-based tool to monitor community drug abuse. Environmental Health: A Global Access Science Source 4, 1-7.

3 ) Zuccato, E., Chiabrando, C., Castiglioni, S., Bagnati, R., Fanelli, R., 2008. Estimating community drug abuse by wastewater analysis. Environmental Health Perspectives 116(8), 10271032.

4 ) Ort, C., van Nuijs, A.L.N., Berset, J.D., Bijlsma, L., Castiglioni, S., Covaci, A., de Voogt, P., Emke, E., Fatta-Kassinos, D., Griffiths, P., Hernández, F., González-Mariño, I., Grabic, R., Kasprzyk-Hordern, B., Mastroianni, N., Meierjohann, A., Nefau, T., Östman, M., Pico, Y., Racamonde, I., Reid, M., Slobodnik, J., Terzic, S., Thomaidis, N., Thomas, K.V., 2014. Spatial differences and temporal changes in illicit drug use in Europe quantified by wastewater analysis. Addiction 109(8), 13381352.

5 ) Australian Criminal Intelligence Commission, 2019. National Wastewater Drug Monitoring Program.

6 ) Choi, P.M., Tscharke, B.J., Donner, E., O’Brien, J.W., Grant, S.C., Kaserzon, S.L., Mackie, R., O'Malley, E., Crosbie, N.D., Thomas, K.V., Mueller, J.F., 2018. Wastewater-based epidemiology biomarkers: Past, present and future. TrAC Trends in Analytical Chemistry 105, 453-469.

7 ) Coutu, S., Wyrsch, V., Wynn, H.K., Rossi, L., Barry, D.A., 2013. Temporal dynamics of antibiotics in wastewater treatment plant influent. Science of the Total Environment 458-460, $20-26$. 
8 ) Golovko, O., Kumar, V., Fedorova, G., Randak, T., Grabic, R., 2014. Seasonal changes in antibiotics, antidepressants/ psychiatric drugs, antihistamines and lipid regulators in a wastewater treatment plant. Chemosphere 111, 418-426.

9 ) Fahrenfeld, N., Bisceglia, K.J., 2016. Emerging investigators series: sewer surveillance for monitoring antibiotic use and prevalence of antibiotic resistance: urban sewer epidemiology. Environmental Science: Water Research \& Technology 2, 788-799.

10) Fattore, E., Davoli, E., Castiglioni, S., Bosetti, C., Re Depaolini, A., Marzona, I., Zuccato, E., Fanelli, R., 2016. Wastewater-based epidemiological evaluation of the effect of air pollution on short-acting beta-agonist consumption for acute asthma treatment. Environmental Research 150, 106-111.

11) Lickness, J.S., Gardner, T., Diop, O.M., Chavan, M., Jorba, J., Ahmed, J., Gumede, N., Johnson, T., Butt, O., Asghar, H., Saxentoff, E., Grabovac, V., Avagyan, T., Joshi, S., Rey-Benito, G., Iber J., Henderson, E., Wassilak, S.G.F., Anand, A., 2020. Surveillance to Track Progress Toward Polio Eradication Worldwide, 2018-2019. Morbidity and Mortality Weekly Report 69, 623-629.

12) Anis, E., Kopel, E., Singer, S.R., Kaliner, E., Moerman, L., Moran-Gilad, J., Sofer, D., Manor, Y., Shulman, L.M., Mendelson, E., Gdalevich, M., Lev, B., Gamzu, R., Grotto, I., 2013. Insidious reintroduction of wild poliovirus into Israel, 2013. Eurosurveillance 18 (38), pii=20586.

13) Farkas, K., Marshall, M., Cooper, D., McDonald, J.E., Malham, S.K., Peters, D.E., Maloney, J.D., Jones, D.L., 2018. Seasonal and diurnal surveillance of treated and untreated wastewater for human enteric viruses. Environmental Science and Pollution Research 25(33), 33391-33401.

14) Kazama, S., Miura, T., Masago, Y., Konta, Y., Tohma, K., Manaka, T., Liu, X., Nakayama, D., Tanno, T., Saito, M., Oshitani, H., Omura, T., 2017. Environmental surveillance of norovirus genogroups I and II for sensitive detection of epidemic variants. Applied and Environmental Microbiology 83(9), e03406-16.

15) Miura, T., Lhomme, S., Le Saux, J.C., Le Mehaute, P., Guillois, Y., Couturier, E., Izopet, J., Abranavel, F., Le Guyader, F.S., 2016. Detection of hepatitis e virus in sewage after an outbreak on a French island. Food and Environmental Virology 8(3), 194-199.

16) Bisseux, M., Colombet, J., Mirand, A., Roque-Afonso, A.M., Abravanel, F., Izopet, J., Archimbaud, C., Peigue-Lafeuille, H., Debroas, D., Bailly, J.L., Henquell, C., 2018. Monitoring human enteric viruses in wastewater and relevance to infections encountered in the clinical setting: a one-year experiment in Central France, 2014 to 2015. Eurosurveillance 23(7), pii=1700237.

17) Hellmér, M., Paxéus, N., Magnius, L., Enache, L., Arnholm, B., Johansson, A., Bergström, T., Norder, H., 2014. Detection of pathogenic viruses in sewage provided early warnings of hepatitis a virus and norovirus outbreaks. Applied and Environmental Microbiology 80(21), 6771-6781.

18）東北大学・山形大学・仙台市 ・ 日水コン共同研究体, 2021. 下 水中ノロウイルス濃度情報発信サイト. URL. https: //novinse wage.com/ (2021 年 3 月時点).

19) Lamers, M., Beumer, J., van der Vaart, J., Knoops, K., Puschhof, J., Breugem, T., Ravelli, R., van Schayck, J.P., Mykytyn, A., Duimel, H., van Donselaar, E., Riesebosch, S., Kuijpers, H., Schipper, D., van de Wetering, W., de Graaf, M., Koopmans, M., Cuppen, E., Peters, P., Haagmans, B., Clevers, H., 2020. SARS-CoV-2 productively infects human gut enterocytes. Science 369 (6499), 50-54.

20) Medema, G., Heijnen, L., Elsinga, G., Italiaander, R., Brouwer, A., 2020. Presence of SARS-Coronavirus-2 RNA in sewage and correlation with reported COVID-19 prevalence in the early stage of the epidemic in the Netherlands. Environmental
Science and Technology Letters 7(7), 511-516.

21) Randazzo, W., Cuevas-Ferrando, E., Sanjuán, R., DomingoCalap, P., Sánchez, G., 2020. Metropolitan wastewater analysis for COVID-19 epidemiological surveillance. International Journal of Hygiene and Environmental Health 230 (September), 113621.

22) Peccia, J., Zulli, A., Brackney, D.E., Grubaugh, N.D., Kaplan, E.H., Casanovas-Massana, A., Ko, A.I., Malik, A.A., Wang, D., Wang, M., Warren, J.L., Weinberger, D.M., Arnold, W., Omer, S.B., 2020. Measurement of SARS-CoV-2 RNA in wastewater tracks community infection dynamics. Nature Biotechnology 38(10), 1164-1167.

23) Kaplan, E.H., Wang, D., Wang, M., Malik, A.A., Zulli, A., Peccia, J., 2021. Aligning SARS-CoV-2 indicators via an epidemic model: application to hospital admissions and RNA detection in sewage sludge. Health Care Management Science 24(2), 320-329.

24）大村達夫, 2020. ウイルス感染症流行防止と下水道を基軸とし た学際的取り組みの必要性. 月刊下水道 43(10), 12-16.

25）国立感染症研究所，2021. 感染・伝播性の増加や抗原性の変化 が懸念される新型コロナウイルス（SARS-CoV-2）の新規変異株 について (第6報). URL. https://www.niid.go.jp/niid/ja/diseases/ $\mathrm{ka} /$ corona-virus/2019-ncov/10169-covid19-35.html（2021年3月 時点).

26) Ahmed, W., Bivins, A., Bertsch, P.M., Bibby, K., Gyawali, P., Sherchan, S.P., Simpson, S.L., Thomas, K.V., Verhagen, R., Kitajima, M., Mueller, J.F., Korajkic, A., 2021. Intraday variability of indicator and pathogenic viruses in 1-h and 24-h composite wastewater samples: implications for wastewaterbased epidemiology. Environmental Research 193, 110531.

27) Kitamura, K., Sadamasu, M., Muramatsu, M., Yoshida, H., 2020. Efficient detection of SARS-CoV-2 RNA in the solid fraction of wastewater. Science of The Total Environment 763 (1), 144587.

28) Ye, Y., Ellenberg, R.M., Graham, K.E., Wigginton, K.R., 2016. Survivability, partitioning, and recovery of enveloped viruses in untreated municipal wastewater. Environmental Science and Technology 50(10), 5077-5085.

29) Haramoto, E., Kitajima, M., Hata, A., Torrey, J.R., Masago, Y., Sano, D., Katayama, H., 2018. A review on recent progress in the detection methods and prevalence of human enteric viruses in water. Water Research 135, 168-186.

30) Ahmed, W., Angel, N., Edson, J., Bibby, K., Bivins, A., O'Brien, J.W., Choi, P.M., Kitajima, M., Simpson, S.L., Li, J., Tscharke, B., Verhagen, R., Smith, W.J.M., Zaugg, J., Dierens, L., Hugenholtz, P., Thomas, K.V., Mueller, J.F., 2020. First confirmed detection of SARS-CoV-2 in untreated wastewater in Australia: a proof of concept for the wastewater surveillance of COVID-19 in the community. Science of The Total Environment 728, 138764.

31) Haramoto, E., Malla, B., Thakali, O., Kitajima, M., 2020. First environmental surveillance for the presence of SARS-CoV-2 RNA in wastewater and river water in Japan. Science of The Total Environment 737, 140405.

32) Torii, S., Furumai, H., Katayama, H., 2020. Applicability of polyethylene glycol precipitation followed by acid guanidinium thiocyanate-phenol-chloroform extraction for the detection of SARS-CoV-2 RNA from municipal wastewater. Science of The Total Environment 756, 143067.

33) Nemudryi, A., Nemudraia, A., Wiegand, T., Surya, K., Buyukyoruk, M., Cicha, C., Vanderwood, K.K., Wilkinson, R., Wiedenheft, B., 2020. Temporal detection and phylogenetic assessment of SARS-CoV-2 in municipal wastewater. Cell Reports Medicine 1(6), 100098.

34) Zhang, D., Ling, H., Huang, X., Li, J., Li, W., Yi, C., Zhang, T., Jiang, Y., He, Y., Deng, S., Zhang, X., Wang, X., Liu, Y., Li, G., $\mathrm{Qu}, \quad$ J., 2020. Potential spreading risks and disinfection challenges of medical wastewater by the presence of severe acute respiratory syndrome coronavirus 2 (SARS-CoV-2) viral 
RNA in septic tanks of Fangcang hospital. Science of The Total Environment 741, 140445.

35) Randazzo, W., Truchado, P., Cuevas-Ferrando, E., Simón, P., Allende, A., Sánchez, G., 2020. SARS-CoV-2 RNA in wastewater anticipated COVID-19 occurrence in a low prevalence area. Water Research 181, 115942.

36) Masago, Y., Konta, Y., Kazama, S., Inaba, M., Imagawa, T., Tohma, K., Mayuko, S., Suzuki, A., Oshitani, H., Omura, T., 2016. Comparative evaluation of real-time PCR methods for human noroviruses in wastewater and human stool. PLoS ONE 11(8), e0160825.

37) Hennechart-Collette, C., Martin-Latil, S., Guillier, L., Perelle, S., 2015. Determination of which virus to use as a process control when testing for the presence of hepatitis A virus and norovirus in food and water. International Journal of Food Microbiology 202 (2), 57-65.

38) Ahmed, W., Bertsch, P.M., Bivins, A., Bibby, K., Farkas, K., Gathercole, A., Haramoto, E., Gyawali, P., Korajkic, A., McMinn, B.R., Mueller, J.F., Simpson, S.L., Smith, W.J.M., Symonds, E.M., Thomas, K.V., Verhagen, R., Kitajima, M., 2020. Comparison of virus concentration methods for the RT-qPCR-based recovery of murine hepatitis virus, a surrogate for SARS-CoV-2 from untreated wastewater. Science of The Total Environment 739, 139960.

39) Kitajima, M., Iker, B.C., Pepper, I.L., Gerba, C.P., 2014. Relative abundance and treatment reduction of viruses during wastewater treatment processes-identification of potential viral indicators. Science of The Total Environment 488-489, 290-296.

40）厚生労働省. 感染症法に基づく医師の届出のお願い. URL. https://www.mhlw.go.jp/stf/seisakunitsuite/bunya/kenkou_ iryou/kenkou/kekkaku-kansenshou/kekkaku-kansenshou11/ 01.html\#h2_free3 (2021 年 3 月時点).

41) Wu, Q., Xuan, Z., Liu, J., Zhao, X., Chen, Y., Wang, C., Shen, X., Wang, Y., Wang, L., Hu, Y., 2019. Norovirus shedding among symptomatic and asymptomatic employees in outbreak settings in Shanghai, China. BMC Infectious Diseases 19, 592.

42) Wölfel, R., Corman, V.M., Guggemos, W., Seilmaier, M., Zange, S., Müller, M.A., Niemeyer, D., Jones, T.C., Vollmar, P., Rothe, C., Hoelscher, M., Bleicker, T., Brünink, S., Schneider, J., Ehmann, R., Zwirglmaier, K., Drosten, C., Wendtner, C., 2020. Virological assessment of hospitalized patients with COVID2019. Nature 581 (7809), 465-469.

43) Teunis, P.F.M., Sukhrie, F.H.A., Vennema, H., Bogerman, J., Beersma, M.F.C., Koopmans, M.P.G., 2015. Shedding of norovirus in symptomatic and asymptomatic infections. Epidemiology \& Infection 143(8), 1710-1717.
44) O’Brien, J.W., Banks, A.P.W., Novic, A.J., Mueller, J.F., Jiang, G., Ort, C., Eaglesham, G., Yuan, Z., Thai, P.K., 2017. Impact of in-sewer degradation of pharmaceutical and personal care products (PPCPs) population markers on a population model. Environmental Science and Technology 51(7), 3816-3823.

45) Been, F., Rossi, L., Ort, C., Rudaz, S., Delémont, O., Esseiva, P., 2014. Population normalization with ammonium in wastewaterbased epidemiology: application to illicit drug monitoring. Environmental Science and Technology 48(14), 8162-8169.

46) Joy, T., Walsh, G., Tokmakejian, S., Van Uum, S.H.M., 2008. Increase of urinary 5-hydroxyindoleacetic acid excretion but not serum chromogranin a following over-the-counter 5-hydroxytryptophan intake. Canadian Journal of Gastroenterology and Hepatology 22(1), 49-53.

47) Symonds, E.M., Nguyen, K.H., Harwood, V.J., Breitbart, M., 2018. Pepper mild mottle virus: a plant pathogen with a greater purpose in (waste) water treatment development and public health management. Water Research 144, 1-12.

48) Bivins, A., Greaves, J., Fischer, R., Yinda, K.C., Ahmed, W., Kitajima, M., Munster, V.J., Bibby, K., 2020. Persistence of SARS-CoV-2 in water and wastewater. Environmental Science and Technology Letters 7(12), 937-942.

49) Ahmed, W., Bertsch, P.M., Bibby, K., Haramoto, E., Hewitt, J., Huygens, F., Gyawali, P., Korajkic, A., Riddell, S., Sherchan, S.P., Simpson, S.L., Sirikanchana, K., Symonds, E.M., Verhagen, R., Vasan, S.S., Kitajima, M., Bivins, A., 2020. Decay of SARS-CoV-2 and surrogate murine hepatitis virus RNA in untreated wastewater to inform application in wastewaterbased epidemiology. Environmental Research 191(August), 110092.

50) Skraber, S., Ogorzaly, L., Helmi, K., Maul, A., Hoffmann, L., Cauchie, H., Gantzer, C., 2009. Occurrence and persistence of enteroviruses, noroviruses and F-specific RNA phages in natural wastewater biofilms. Water Research 43(19), 47804789.

51) Kauppinen, A., Miettinen, I.T., 2017. Persistence of norovirus GII genome in drinking water and wastewater at different temperatures. Pathogens 6(4), 48.

52) Zhu, Y., Oishi, W., Saito, M., Kitajima, M., Sano, D., 2021. Early warning of COVID-19 in Tokyo via wastewater-based epidemiology: How feasible it really is? Journal of Water and Environment Technology 19(3), 170-183.

53）国立感染症研究所, 2013. 世界保健機関 感染性物質の輸送規 則に関するガイダンス 2013-2014版 (日本語版). URL. https:// www.niid.go.jp/niid/images/biosafe/who/WHOguidance_ transport13-14.pdf（2021 年 4 月時点）.

\section{[論 文 要 旨]}

新型コロナウイルス感染症の世界的な大流行の中, 下水疫学調査による感染流行規模の把握や変異株の早 期検知が期待されている。本稿では, ウイルス感染症対策における下水疫学調査の実装に必要な要素および 課題を解説した。下水疫学調査の実装のためには, 下水試料の採取方法と濃縮方法の最適化および下水中ウ イルス濃度に基づく感染者数推定モデルの構築が必須である。日本国内においては，感染症が定点把握疾患 に分類される場合において，下水処理場の流入下水の分析結果を用いて早期検知が可能である。感染者数推 定モデルの構築においては，感染症に共通の変数と感染症ごとに特有の変数が存在する。感染者のウイルス 排出プロファイル等の個人差や処理区域人口の日内変動等に起因する変数の変動性や不確実性に対応可能な モデルの構築に引き続き取り組んでいく必要がある。

$$
\text { キーワード : 新型コロナウイルス感染症 ; 下水疫学 ; 早期検知 }
$$


